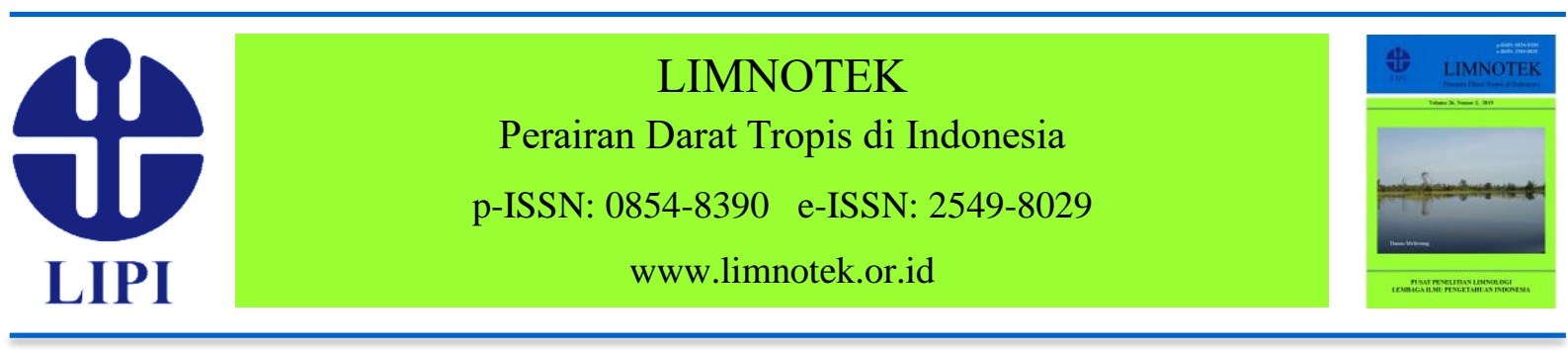

\title{
Penentuan Batas Tepi Danau Paparan Banjir Secara Hitung Perataan Kuadrat Terkecil dengan Multidata Pengindraan Jauh
}

\author{
Atriyon Julzarika ${ }^{1,2}$, Esthi Kurnia Dewi ${ }^{1}$, Luki Subehi ${ }^{3}$ \\ ${ }^{1}$ Pusat Pemanfaatan Penginderaan Jauh LAPAN, \\ ${ }^{2}$ Teknik Geodesi Geomatika UGM, \\ ${ }^{3}$ Pusat Penelitian Limnologi, Lembaga Ilmu Pengetahuan Indonesia \\ *Email: verbhakov@yahoo.com
}

Diajukan 20 Juli 2018. Ditelaah 5 Maret 2019. Disetujui 29 November 2019.

\begin{abstract}
Abstrak
Saat ini teknologi dan data pengindraan jauh telah berkembang secara signifikan. Perkembangan tersebut dimulai dari data konvensional sampai menjadi data dinamis. Teknologi dan data pengindraan jauh dapat diaplikasikan dalam pemetaan sumber daya perairan darat yang meliputi danau, sungai, dan rawa. Sumber daya perairan darat merupakan salah satu prioritas nasional, terutama dalam pemetaan danau. Salah satu permasalahan danau dengan tipe paparan banjir adalah sulit dalam menentukan batas tetap luas permukaan danaunya. Penelitian ini bertujuan untuk mendapatkan pemetaan batas tetap danau secara geologi forensik dengan pendekatan pengaturan kuadrat terkecil pada danau tipe paparan banjir dengan multidata pengindraan jauh. Danau tipe paparan banjir yang dikaji adalah Danau Kaskade Mahakam di Provinsi Kalimantan Timur. Batas tetap luas permukaan danau ini ditentukan dengan pendekatan hitung perataan kuadrat terkecil. Salah satu metode dalam perataan adalah harmonic modeling algorithm. Pemetaan ini menggunakan multidata pengindraan jauh berupa Synthethic Aperture Radar (SAR) dan citra optik. Citra yang digunakan adalah Sentinel-1 yang diakuisisi dari tahun 2014 sampai dengan 2018 dan Landsat dari tahun 2014 sampai 2018. Hasil penggunaan algoritma ini adalah batas tetap Danau Kaskade Mahakam dapat ditentukan dengan toleransi tertentu. Batas tetap ini mengabaikan parameter pasang danau karena nilai pasang di danau maksimal hanya $+5 \mathrm{~cm}$. Nilai pasang ini diabaikan karena akurasi vertikal data topografi di big data engine sekitar $2 \mathrm{~m}$. Batas tepi danau dapat dimanfaatkan untuk penentuan volume dan luas permukaan danau. Luas permukaan danau yang diperoleh dari citra Sentinel-1 sebesar $\sim 399,017 \mathrm{~km}^{2}$. Berdasarkan citra Landsat, luas permukaan danau yang diperoleh $\sim 399,495 \mathrm{~km}^{2}$. Perbedaan tersebut disebabkan ada pencampuran sedimen dan kekeruhan tipis di pinggir danau. Kondisi ini menyebabkan perbedaan nilai reflektansi pada saat perekaman kedua jenis citra tersebut. Pada dasarnya, metode ini dapat digunakan untuk menentukan batas tepi danau.
\end{abstract}

Kata kunci: danau tipe paparan banjir, big data engine, hitung perataan kuadrat terkecil, batas tepi danau, harmonic modeling 


\begin{abstract}
Determination of Flood-plain Lake Edge Limits with Calculating Smallest Squared Flattening by Remote Sensing Multidata. Nowadays, technology and remote sensing data have developed significantly. These developments started with conventional data to become dynamic data. Technology and remote sensing data can be used for various applications such as mapping of inland water. Inland water resources that include lakes, rivers, and swamps are one of the national priorities, especially in lake mapping. One of the problems with floodplain lakes is that it is difficult to determine the fixed boundaries of the lake surface area. This study aims to obtain a forensic geological boundary mapping of a lake using the least-square adjustment approach in a floodplain lake with multi-data remote sensing. The floodplain lake in this study was Mahakam Cascade Lake in East Kalimantan Province. The fixed boundary of the surface area of the lake was determined using the least-square adjustment approach. One method in the adjustment was the harmonic modeling algorithm. This mapping used multi-data remote sensing in the form of Synthetic Aperture Radar (SAR) and optical imagery. The imagery used was Sentinel-1 which was acquired from 2014 to 2018 and Landsat from 2014 to 2018. This algorithm showed that the fixed boundaries of Mahakam Cascade Lake can be determined with certain tolerances. These fixed boundaries ignored lake tide parameters because the maximum tide value in the lake was only $+5 \mathrm{~cm}$. This value was ignored because the vertical accuracy of the topographic data in the big data engine was about $2 \mathrm{~m}$. The fixed delineation of lake edges can be used to determine the lake volume and surface area. The surface area of the lake obtained from the Sentinel-1 imageries was $\sim 399,017 \mathrm{~km}^{2}$. Based on Landsat imageries, the surface area of the lake was $\sim 399,495 \mathrm{~km}^{2}$. The difference was due to the mixing of sediments and thin turbidity at the edge of the lake. This condition caused differences in reflectance values when acquisitioning the two types of imageries. Basically, this method could be applied for determining the edge of a lake.
\end{abstract}

Keywords: floodplain lake, big data engine, least-square adjustment, fixed delineation of lake, harmonic modeling

\section{Pendahuluan}

Danau dapat terjadi karena gletser yang mencair, aliran sungai, atau terdapat mata air (Asdak, 2014). Danau dapat berupa akumulasi air tawar atau asin di tempat yang luas. Dalam skala global, danau telah menjadi perhatian dunia karena $90 \%$ air tawar di permukaan bumi tersimpan di danau dan waduk. Ekosistem DAS dan danau di wilayah Indonesia menyimpan kekayaan $25 \%$ plasma nutfah dunia, menyuplai $72 \%$ air permukaan dan menyediakan air untuk pertanian, sumber air baku masyarakat, pertanian, pembangkit listrik tenaga air, pariwisata, dan lain-lain (Kementerian Lingkungan Hidup Republik Indonesia, 2008).

Saat ini ada 15 danau prioritas di Indonesia (Kementerian Lingkungan Hidup Republik Indonesia, 2011). Lima belas danau prioritas tersebut meliputi Danau Toba di Sumatra Utara, Danau Maninjau dan Danau Singkarak di Sumatra Barat, Danau Kerinci di Jambi, Danau Rawadano di Banten, Danau Rawapening di Jawa Tengah, Danau Batur di Bali, Danau Tempe dan Danau Matano di
Sulawesi Selatan, Danau Poso di Sulawesi Tengah, Danau Tondano di Sulawesi Utara, Danau Limboto di Gorontalo, Danau Sentarum di Kalimantan Barat, Danau Kaskade Mahakam (Danau Semayang, Danau Melintang, dan Danau Jempang) di Kalimantan Timur, dan Danau Sentani di Papua. Selain 15 danau prioritas tersebut, masih ada danau yang perlu difokuskan penanganannya, seperti keunikan danau air asin Danau Oemasapoka, Danau Oeinalaen, dan Danau Bisaduli di Pulau Rote, Nusa Tenggara Timur (Julzarika et al., 2018).

Data pengindraan jauh telah berkembang dari konvensional menjadi dinamis (Kumay, 2015). Salah satu contoh data dinamis ini adalah big data engine yang mencakup data pengindraan jauh sensor optik dan radar. Big data engine adalah platform untuk analisis ilmiah skala petabyte dan visualisasi dataset geospasial, baik untuk kepentingan publik maupun untuk pengguna bisnis dan pemerintah. Big data engine menyimpan citra satelit, mengaturnya, dan menyediakannya untuk pertama kalinya dalam penambangan data berskala global. Arsip data publik mencakup 
historis citra bumi yang sudah ada sejak lebih dari empat puluh tahun, dan citra baru yang dikumpulkan setiap hari. Big data engine juga menyediakan Application Program Interface (API) dalam JavaScript dan Python, serta alatalat lain untuk memungkinkan analisis dataset besar (GEE, 2018). Beberapa contoh citra yang terdapat di big data engine adalah Landsat, Sentinel, ALOS PALSAR, Worldview, Ikonos, GeoEye, QuickBird, dan MODIS. Citra Landsat dimulai pada tahun 1972 dan masih berlanjut sampai saat ini.

Big data engine juga menyediakan berbagai informasi tematik dan pembuatan algoritma sesuai kebutuhan aplikasi pengguna. Big data engine dapat memfasilitasi pengolahan awal, ekstraksi informasi geobiofisik, dan penyajian informasi spasialnya. Big data engine ini bersifat dinamis dan cepat dalam pengolahannya yang bergantung pada internet dan cloud data. Selain itu, big data engine dapat dimanfaatkan di bidang sumber daya perairan darat, khususnya danau. Citra Sentinel dan Landsat lebih banyak dimanfaatkan karena memiliki temporal tinggi dan ketersediaan data lebih banyak.

Misi Sentinel-1 didasarkan pada konstelasi dua satelit identik, yaitu Sentinel-1A (diluncurkan pada April 2014) dan Sentinel-1B (diluncurkan pada April 2016). Kedua satelit terbang dalam bidang orbital yang sama dengan fase $180^{\circ}$ di orbit dan masing-masing memiliki siklus pengulangan orbit 12 hari. Hal ini akan memfasilitasi pembentukan pasangan gambar interferometri SAR (misalnya interferogram) yang memiliki interval waktu 6 hari dari konstelasi dua-satelit di khatulistiwa (ESA, 2018). Misi Sentinel-1 beroperasi siang dan malam dengan melakukan pencitraan SAR Cband, sehingga memungkinkan untuk memperoleh citra tanpa memperhatikan cuaca. Sentinel-1 bekerja dalam mode operasi pradiprogram untuk menghindari konflik dan menghasilkan arsip data jangka panjang yang konsisten yang dibangun untuk aplikasi berdasarkan seri waktu yang lama. Sentinel-1 adalah yang pertama dari lima misi yang dikembangkan ESA untuk inisiatif Copernicus.

Landsat merupakan satelit milik United States of Geological Survey (USGS) yang memiliki misi untuk survei pemetaan geologi dan sumber daya alam (USGS, 2018). Saat ini Landsat telah memasuki generasi kedelapan.
Contoh pemanfaatan data pengindraan jauh di danau antara lain pemetaan lahan kritis, estimasi koefisien aliran, sebaran spasial debit permukaan, tingkat erosi tanah, pemetaan kualitas air, luas permukaan danau, batas tepi danau, dan kualitas danau (Tang et al., 2016; Trisakti et al., 2016; Li \& Li, 2004). Pemetaan lahan kritis umumnya dilakukan dengan menggunakan parameter penutupan lahan, lereng, erosi, dan manajemen lahan. Penghitungan debit air dan erosi memerlukan parameter masukan utama, yaitu penutup lahan, kelerengan, dan jenis tanah (Trisakti et al., 2014). Sebagian besar parameter yang dibutuhkan tersebut dapat diturunkan secara akurat dengan menggunakan data pengindraan jauh satelit (Definiens, 2016).

Pemanfaatan data pengindraan jauh di bidang perairan darat dapat digunakan untuk pemantauan dan evaluasi kualitas ekosistem danau, serta perubahan penutup lahan di daerah aliran sungai dan di sekitar danau (Karimi \& Bastiaanssen, 2015; Kartika et al., 2015; Priasty, 2014) pemantauan perubahan luas permukaan danau (Buma et al., 2018; Pekel et al., 2016; Trisakti et al., 2013; Mostafa \& Soussa, 2006), pemetaan dan penilaian tingkat kualitas air danau (Liu et al., 2007; Doxaran et $a l ., 2002)$, pendugaan debit air dan estimasi laju erosi tanah di daerah tangkapan air, daerah aliran sungai, dan di sekitar danau (Pratisto \& Danoedoro, 2008; Suroso \& Susanto, 2006; Honda et al., 1996). Lebih jauh pada tingkat operasional, Brezonik et al. (2002) mengembangkan model algoritma ekstraksi klorofil, kejernihan perairan, dan Total Suspended Solid (TSS) di perairan danau. Kemudian Powell et al. (2008) menerapkan model tersebut untuk memantau perubahan indeks status trofik perairan danau di Amerika dan Kanada secara operasional. Deteksi batas danau ini dipengaruhi oleh kualitas citra satelit yang digunakan. Reflektivitas radiometrik citra berpengaruh dalam pemisahan batas danau. Umumnya pada citra yang koreksi radiometrik belum dilakukan akan terjadi percampuran air danau dengan daratan, vegetasi air, dan aliran permukaan sungai ke danau. Status trofik ini berpengaruh dalam pemisahan campuran danau dan daratan.

Selain status trofik, beberapa parameter lain perairan danau yang juga telah dipantau secara operasional menggunakan gabungan antara teknologi pengindraan jauh dan sistem 
informasi geografis adalah luas permukaan air, level muka air, suhu, dan TSS di wilayah Macedonia bagian barat, Yunani (Marianthi et al., 2011). Selain itu, data pengindraan jauh juga digunakan untuk memantau perubahan luas permukaan air danau yang mencakup penyusutan dan perluasannya (Hickmat et al., 2016) seperti danau-danau dengan ukuran kecil di tenggara Brazil (Maillard et al., 2012), memantau pertumbuhan vegetasi air di Danau Malheur, Oregon (Adjei, 2015), mendeteksi dan memprediksi lingkungan sekitar danau dengan data multitemporal (Kamran et al., 2018; Bayr et al., 2016; Benjamin et al., 2016; Zheng et al., 2014), data tambahan dan pengindraan jauh (Duan et al., 2018; Tauro et al., 2018; Wasige, 2013), klasifikasi daerah semi kering (Blanco et $a l .$, 2014), topografi daerah aliran sungai (Duan et al., 2016; Gao et al., 2014), aliran hidrologi permukaan (Blume et al., 2017; Senay et al., 2014), serta pendekatan harmonic modeling Landsat (Wilson et al., 2018). Baig et al. (2014) melakukan penelitian terkait derivasi transformasi tasseled cap pada Landsat 8 dengan kondisi sudah dalam bentuk reflektivitas. Indeks vegetasi multitemporal juga dapat digunakan untuk mendeteksi informasi geobiofisik (Zhu et al., 2015). Luas permukaan danau ini berpengaruh dalam penentuan batas danau. Citra satelit harus telah dikoreksi geometri untuk mendapatkan luas permukaan yang lebih valid, sehingga diperoleh batas tepi danau yang valid juga. Berbagai jenis parameter geobiofisik berpengaruh pada geometri luas permukaan dan batas tepi danau.

Luas permukaan danau ditentukan oleh batas tepi danau dengan daratan. Pada danau bertipe vulkanik, tektonik, tekto-vulkanik, dan bendungan masalah signifikan dalam penentuan batas tepi danau tidak ditemukan. Penentuan batas tepi danau akan bermasalah pada danau bertipe paparan banjir (floodplain). Ada banyak danau paparan banjir di Indonesia seperti Danau Kaskade Mahakam dan Danau Oehala Rote. Danau paparan banjir yaitu danau yang terbentuk akibat genangan banjir dalam cekungan topografi. Salah satu permasalahan danau paparan banjir adalah kompleksitas dalam menentukan batas tetap luas permukaannya. Selain itu, saat ini juga belum ada peraturan mengenai sempadan danau yang mengakibatkan penambahan tanah di sekitar danau. Hidayat et al. (2012) menentukan batas air di daerah genangan banjir dengan backscatter radar. Data radar tersebut menggunakan ALOS PALSAR. Daerah yang terendam penuh dapat dengan mudah dikenali dalam gambar radar dari tanda gelap. Kejadian banjir air terbuka dipetakan menggunakan nilai ambang yang diambil dari backscatter radar dari sungai dan daerah danau yang terendam secara permanen. Analisis intensitas backscatter radar dari area dataran banjir vegetasi mengungkapkan secara konsisten nilai backscatter tinggi yang menunjukkan banjir di bawah kanopi hutan (Hidayat et al., 2012).

Batas tetap danau paparan banjir dapat ditentukan secara geologi forensik dengan multidata pengindraan jauh. Geologi forensik ini menggunakan metode harmonic modeling yang merupakan salah satu pengembangan metode pengaturan kuadrat terkecil. Multidata ini berupa multitemporal citra Sentinel-1 dalam big data engine yang bisa digunakan untuk mengetahui perubahan kondisi wilayah (Canty, 2010; Coppin et al., 2004).

Harmonic modeling menggunakan citra multitemporal. Geerken (2009) menyarankan penggunaan antara tiga dan lima pemodelan harmonik untuk citra seri waktu, serta mencatat bahwa antara $81 \%$ dan $99 \%$ dari varian dalam dataset referensi citra optik dijelaskan oleh urutan deret Fourier ketiga. Pemodelan harmonik ini sesuai dengan siklus sekitar dua belas dan enam bulan. RMSE adalah standar deviasi residual (kesalahan prediksi) yang digunakan dalam model regresi, sehingga menghasilkan koefisien total 9, 15, 21, atau 27. Root Mean Square Error (RMSE) untuk setiap urutan deret Fourier juga disimpan sebagai gambar tiga band. RMSE adalah standar deviasi residual atau kesalahan prediksi.

Geologi forensik dapat didefinisikan sebagai subdisiplin dari geosains yang menyangkut penerapan informasi dan metodologi geologi dan lingkungan untuk menyelidiki kasus-kasus hukum dan masalah forensik kebumian. Menurut Pye et al. (2004), geologi forensik menyangkut segala aspek material bumi, termasuk batu, sedimen, tanah, air dan udara, serta fenomena dan proses alam yang lebih luas. Menurut The International Union of Geological Sciences Initiative on Forensic Geology (IUGS-IFG), geologi forensik melibatkan aplikasi geosains dalam aspek sejarah, kepolisian, investigasi hukum, yang dapat secara relevan berkaitan dengan kasus hukum yang dihadapi. Geologi forensik 
sendiri tidak begitu dikenal pada awalnya, sampai pada saat penerbitan buku pertama mengenai geologi forensik pada tahun 1975 .

Dinamika pasang surut di danau umumnya sebesar maksimal $+5 \mathrm{~cm}$, sehingga bisa diabaikan dalam penentuan batas tepi danau. Nilai pasang ini diabaikan karena akurasi vertikal data topografi big data engine sekitar $2 \mathrm{~m}$. Akurasi vertikal data topografi tertinggi saat ini adalah Lidar sebesar $\sim 20 \mathrm{~cm}$. Pemetaan batas tepi danau berdasarkan pengindraan jauh lebih fokus ke presisi, sedangkan akurasi lebih menggunakan validasi lapangan. Akurasi adalah tingkat kedekatan atau konsistensi pengukuran terhadap nilai yang benar (true value), sedangkan presisi adalah kedekatan pengukuran terhadap nilai rerata (Soetaat, 1996). Penelitian ini bertujuan untuk menentukan batas tepi danau dengan multidata pengindraan jauh menggunakan algoritma harmonic modeling.

\section{Bahan dan Metode}

\section{Lokasi Penelitian}

Penelitian dilakukan di Danau Kaskade Mahakam yang merupakan kompleks danau di aliran Sungai Mahakam, Provinsi Kalimantan Timur (Gambar 1). Danau-danau tersebut meliputi Danau Semayang ( \pm 13.000 ha), Danau Melintang $( \pm 11.000$ ha) di Kabupaten Kutai Kartanegara, dan Danau Jempang ( \pm 15.000 ha) di Kabupaten Kutai Barat. Danau Kaskade
Mahakam adalah salah satu dari 15 danau besar yang ditetapkan sebagai danau kritis di Indonesia berdasarkan penelitian dari LIPI tahun 2011. Berdasarkan Rencana Tata Ruang Wilayah (RTRW) Provinsi Kalimantan Timur, kawasan tiga danau ini (Jempang, Semayang, Melintang) juga ditetapkan sebagai kawasan strategis fungsi dan daya dukung lingkungan hidup Provinsi Kalimantan Timur.

\section{Metode}

Danau Kaskade Mahakam dipilih berdasarkan dinamika hidrologinya yang fluktuatif karena perubahan luas permukaan terjadi secara signifikan setiap tahun, selain karena danau ini mencakup wilayah yang luas. Diagram alir penelitian ini diperlihatkan dalam Gambar 2.

Metode yang digunakan dalam penentuan batas tepi Danau Kaskade Mahakam adalah hitung perataan kuadrat terkecil. Hitung perataan kuadrat terkecil dimaksudkan untuk mendapatkan harga estimasi dari suatu parameter yang paling mendekati harga sebenarnya dengan cara menentukan besaran yang tidak diketahui (parameter) dari sekumpulan data ukuran yang mempunyai pengamatan lebih (Freeden et al., 2010; Soetaat, 1996). Prinsip penyelesaian hitung perataan kuadrat terkecil adalah bila jumlah kuadrat dari residu $\left(\Sigma \mathrm{V}_{\mathrm{i}}^{2}\right)$ minimal (Gillani et al., 2006; Soetaat, 1996).

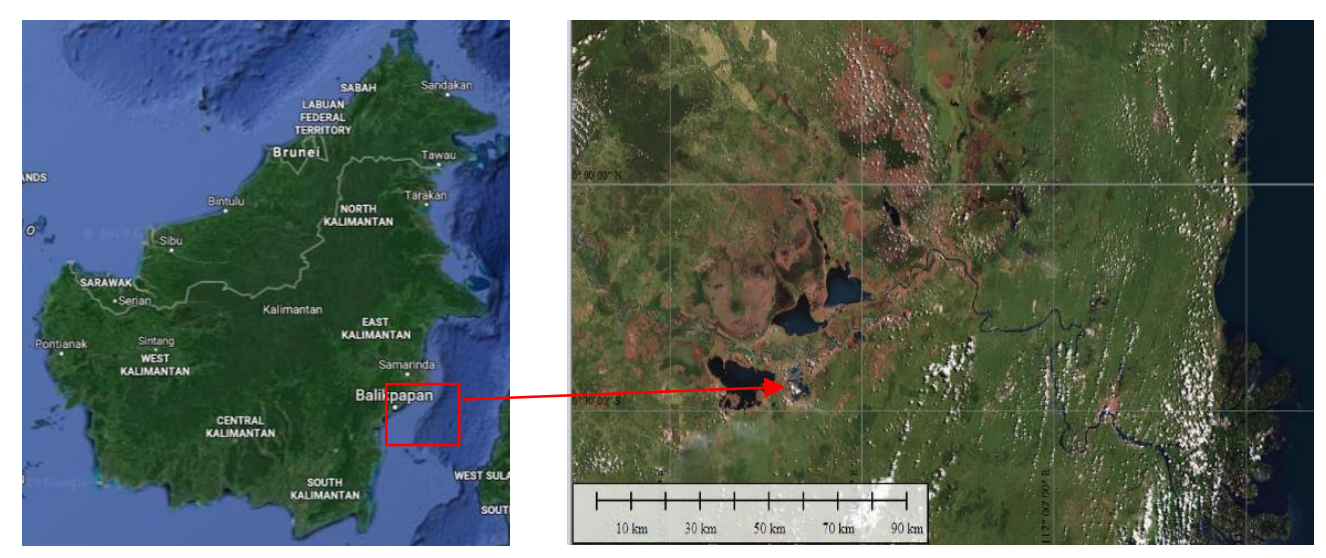

Gambar 1. Danau Kaskade Mahakam, Kalimantan Timur 


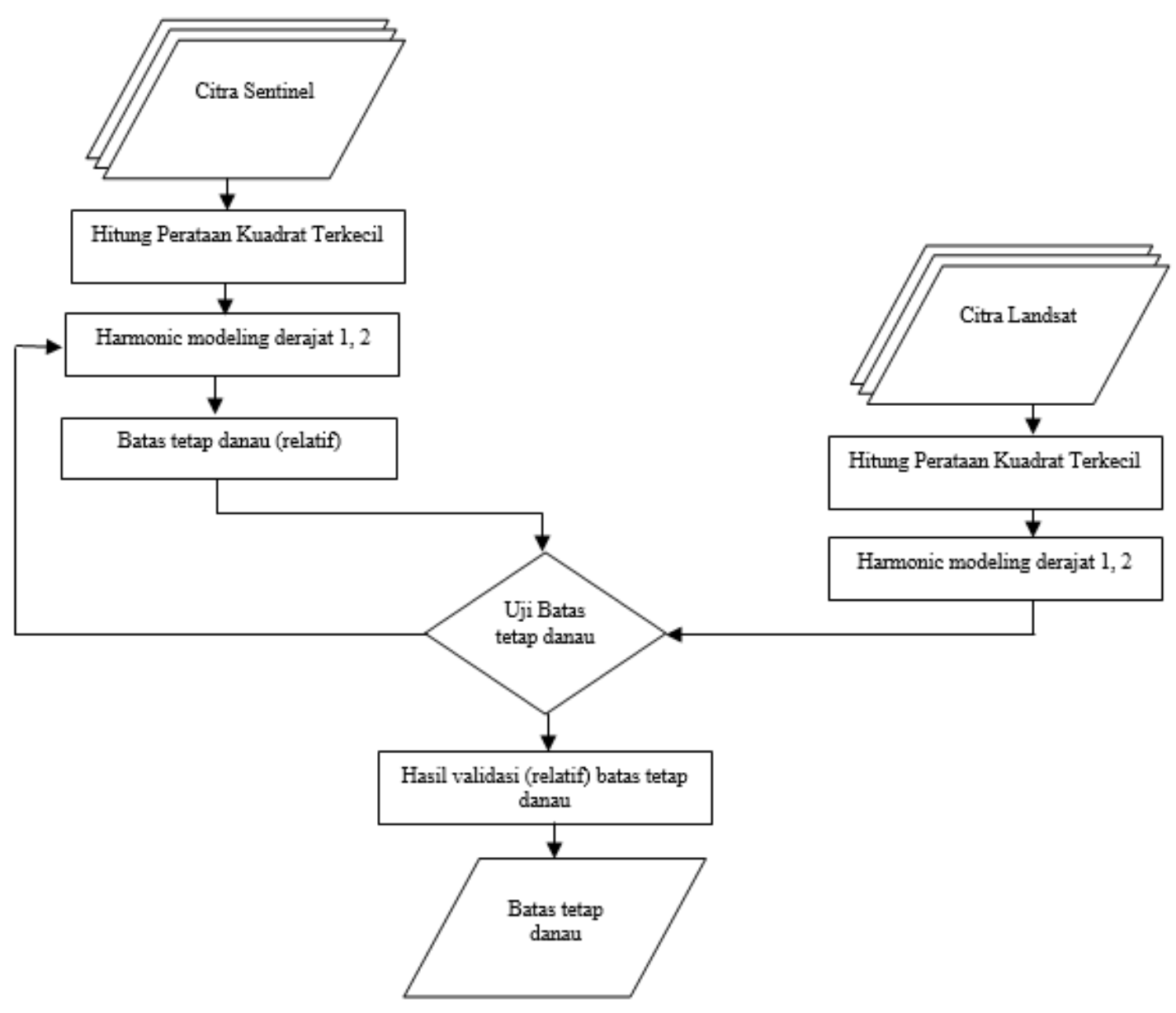

Gambar 2. Diagram alir penelitian

Hitung perataan dipengaruhi oleh faktor akurasi dan presisi (Wolf, 1981). Besar parameter ditentukan dengan persamaan:

$$
\mathrm{X}=-(\mathrm{ATPA})^{-1} \mathrm{ATPF}
$$

\section{Keterangan:}

$\mathrm{X}=$ matriks parameter transformasi

$\mathrm{A}=$ matriks desain/model transformasi koordinat

$\mathrm{F}=$ matriks pengukuran koordinat (c)

$\mathrm{P}=$ matriks bobot penghitungan nilai matriks residu $\mathrm{v}$

$\mathrm{v}=$ matriks residu/koreksi pengamatan

$\mathrm{v}=\mathrm{A} * \mathrm{X}+\mathrm{F}$

Iterasi kedua dilakukan jika $\frac{\hat{\sigma}_{o i}-\hat{\sigma}_{o i+1}}{\hat{\sigma}_{o i}}$

$>$ toleransi atau a posteriori varian $\hat{\sigma}_{0}^{2}>$ toleransi. Nilai toleransi ini ditetapkan berdasarkan tingkat kepercayaan secara geostatistik, minimal tingkat kepercayaan 90\%

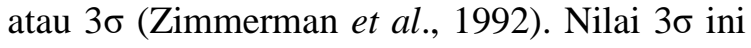
merupakan batas maksimal untuk kesalahan blunder. Dalam setiap hitung perataan kuadrat terkecil diasumsikan bahwa perkiraan apriori dari deviasi standar tersedia dan digunakan untuk menentukan matriks varian. Kebalikan dari matriks apriori varian, umumnya dikenal sebagai matriks bobot. Nilai-nilai dalam kolom deviasi standar dalam perataan adalah perkiraan apriori yang digunakan sistem dalam penyesuaiannya. A posteriori kovarian adalah elemen yang penting untuk mengevaluasi solusi optimasi dalam perataan. A posteriori kovarian berguna dalam kriteria untuk penyesuaian penentuan parameter. Matriks kovarian dapat dihitung selama optimasi.

Faktor a priori varian adalah faktor yang memengaruhi pengamatan, yang sudah 
diketahui sebelumnya. Misalnya saat melakukan survei, faktor a priori varian yang lebih besar akan dipilih ketika cuaca sedang hujan dibandingkan dengan saat panas, untuk mendukung kualitas pengukuran dan pemetaan. Selain itu, matriks kovarian selalu merupakan fungsi dari faktor a priori varian. Faktor a posteriori varian adalah faktor yang dihitung setelah perataan. Hal ini pada dasarnya merupakan perkiraan faktor a priori varian dan menunjukkan varian dari residu. Kondisi ini dapat dicapai dengan merumuskan ulang matriks bobot untuk memasukkan faktor a priori varian dan a posteriori varian dalam penghitungan batas tetap danau. Validasi dengan uji batas tetap danau dan grafik harmonic modeling daratan dan air menggunakan persamaan hitung perataan (Zimmerman et al., 1992), khususnya di bagian matriks parameter (Persamaan 1).

Ekstraksi luas permukaan danau dilakukan dengan metode harmonic modeling secara hitung perataan kuadrat terkecil. Persamaan 3 digunakan untuk mengekstraksi luas permukaan danau dengan metode harmonic modeling. Metode ini menggunakan pendekatan hitung perataan kuadrat terkecil, yaitu regresi Ordinary Least Squares (OLS) yang diperlihatkan dalam Persamaan 2. Regresi OLS digunakan untuk menyesuaikan deret Fourier terpisah untuk setiap rangkaian waktu komposit dari tiga matriks tasseled cap transformation (TCT) untuk setiap piksel di area studi. Analisis deret Fourier dapat digunakan pada regresi OLS tersebut (Artis et al., 2007) dan setiap rangkaian waktu data diperkirakan sebagai polinomial trigonometri.

$$
\widehat{Y}_{t}=a_{0}+\sum_{j=1}^{m}\left(a_{j} \cos \frac{j 2 \pi t}{n}+b_{j} \sin \frac{j 2 \pi t}{n}\right)
$$

\section{Keterangan:}

$$
\begin{array}{ll}
\hat{Y}_{\mathrm{t}} & =\text { rangkaian waktu data } \\
\mathrm{a}_{0}, \mathrm{a}_{\mathrm{j}}, \mathrm{b}_{\mathrm{j}} & =\text { koefisien parameter transformasi } \\
\mathrm{t} & =\text { nilai komposit timestamp } \\
\mathrm{n} & =\text { panjang siklus } \\
\mathrm{m} & =\text { urutan polinomial (jumlah harmonik } \\
& \text { dalam aproksimasi) }
\end{array}
$$

Timestamp waktu citra Landsat disimpan sebagai milidetik sejak awal waktu (1 Januari 1970) dan dikonversi ke hari ephemeris. Nilai 365,2421891 hari ephemeris per tahun tropis digunakan sebagai lama siklus tahunan.
Model regresi dari satu hingga empat harmonik, yaitu dari urutan pertama ke urutan keempat deret Fourier, diuji untuk menentukan bentuk model yang memberikan kecocokan terbaik untuk data tanpa memperkenalkan osilasi palsu (Bradley et al., 2007; Hermance, 2007). Proses harmonik hanya digunakan untuk evaluasi model regresi harmonik, bukan sebagai data tambahan.

$$
\begin{aligned}
& \mathrm{F}^{*}(\text { DOY }) \equiv \mathrm{f}(\mathrm{t})=\mathrm{a}_{0}+\sum_{\mathrm{j}=1}^{\mathrm{n}}\left(\mathrm{b}_{\mathrm{j}} \cos 2 \pi \mathrm{jt}+\mathrm{c}_{\mathrm{j}} \sin 2 \pi \mathrm{jt}\right) \\
& \mathrm{t}=\frac{\left[\mathrm{DOY}-\mathrm{G}_{\mathrm{B}}\right]_{\bmod 365}}{\left[\mathrm{G}_{\mathrm{E}}-\mathrm{G}_{\mathrm{B}}\right]_{\bmod 365}} \in[0,1]
\end{aligned}
$$

Keterangan:

DOY = Day of Year (hari pada tahun tersebut)

$\mathrm{G}_{\mathrm{B}} \quad=$ awal akuisisi citra dengan asumsi tertentu

$\mathrm{G}_{\mathrm{E}}=$ akhir akuisisi citra dengan asumsi tertentu

$\mathrm{t}=$ waktu relatif (dimensi kurang) dalam waktu akuisisi

$\mathrm{n} \quad=$ jumlah total harmonik

$\mathrm{j} \quad=$ jumlah suku harmonik

$\mathrm{a}_{0}, \mathrm{~b}_{\mathrm{j}}, \mathrm{c}_{\mathrm{j}}=$ koefisien harmonik (dihitung dengan menggunakan standar)

f kecil digunakan, bukan $F^{*}$, untuk membedakan fungsi DOY dari fungsi waktu normalisasi $\mathrm{t}$

$[\cdot] \operatorname{modM}$ berarti operasi modulo $\mathrm{M}$, yang masuk akal untuk wilayah dengan GB lebih besar daripada GE (misalnya, di belahan bumi selatan)

$\mathrm{M}=365$ karena 365 adalah interval waktu terpanjang antara dua hari yang berbeda dalam satu tahun.

\section{Data}

Penelitian ini menggunakan data dari big data engine berupa Sentinel-1 dan Landsat. Penentuan batas danau dengan algoritma harmonic modeling dilakukan secara hitung perataan kuadrat terkecil menggunakan data Sentinel-1 dari tahun 2014 hingga 2018. Harmonic modeling dilakukan pada data Sentinel-1 tersebut per tahun. Gambar 3 menjelaskan citra Sentinel tahun 2014 dan 2015.

Pada citra Sentinel-1 tahun 2014, derajat harmonik yang digunakan adalah 1 dan 2. Pada 
tahun tersebut, Danau Kaskade Mahakam berada dalam kondisi normal, yaitu luas permukaan danau tidak berubah secara signifikan antara musim kemarau dan musim hujan. Pada data citra Sentinel-1 tahun 2015, derajat harmonik yang digunakan adalah 1 dan 2. Danau Kaskade Mahakam berada dalam kondisi kering sepanjang tahun 2015, sehingga luas permukaan danau kecil. Luas batas permukaan danau kaskade juga makin menyempit dan terjadi penambahan penutup lahan tanah terbuka. Volume air makin sedikit karena jumlah air yang masuk ke inlet danau sedikit. Hal ini juga berdampak pada air yang keluar di outlet danau yang mengalir ke Sungai Mahakam.

Pemantauan tahun 2016 dan 2017 juga menggunakan citra Sentinel-1 (Gambar 4). Derajat harmonik yang digunakan adalah 1 dan 2. Luas permukaan Danau Kaskade Mahakam dalam kondisi meningkat karena ada penambahan luas selama musim hujan.

Data Sentinel-1 juga digunakan untuk harmonic modeling pada tahun 2018 (Gambar 5) dengan derajat harmonik 1 dan 2. Luas permukaan Danau Kaskade Mahakam dalam kondisi meningkat karena ada penambahan luas permukaan pada musim hujan.
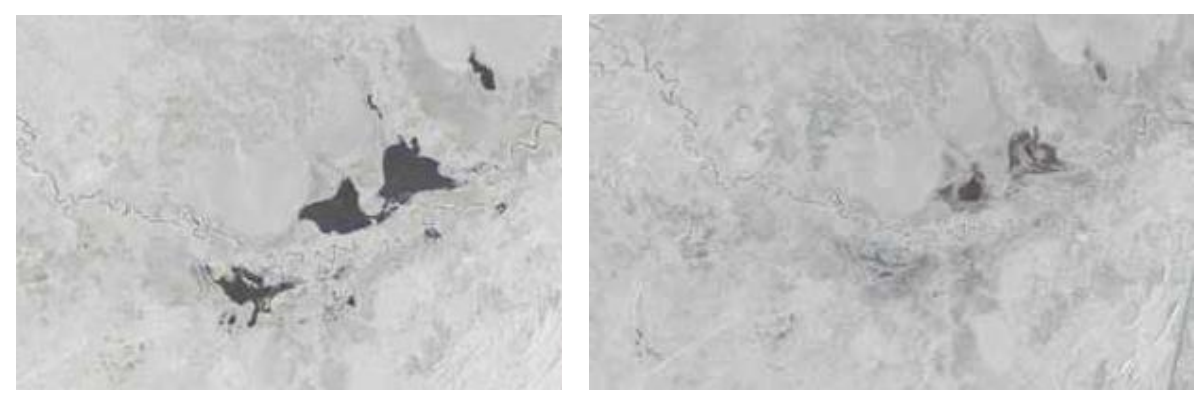

Gambar 3. Citra Sentinel-1 tahun 2014 (kiri) dan 2015 (kanan)
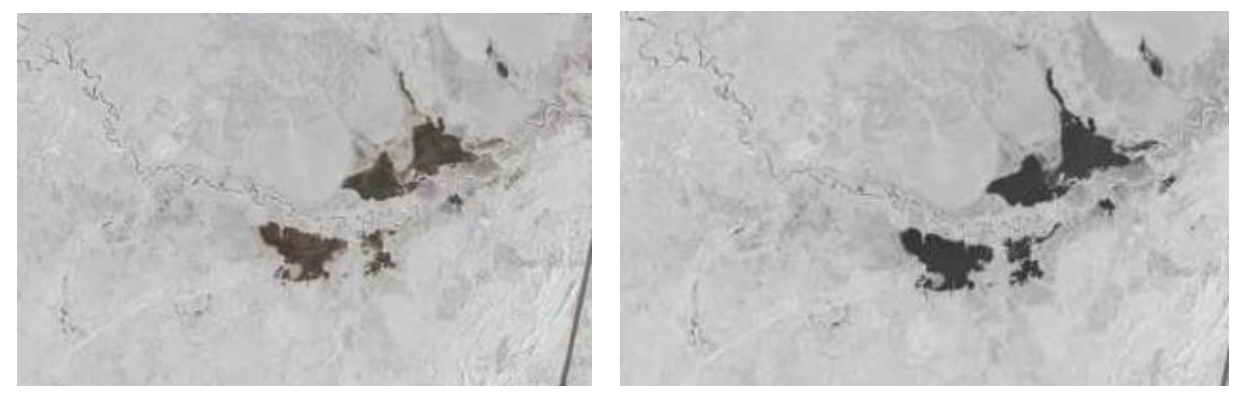

Gambar 4. Citra Sentinel-1 tahun 2016 (kiri) dan 2017 (kanan)

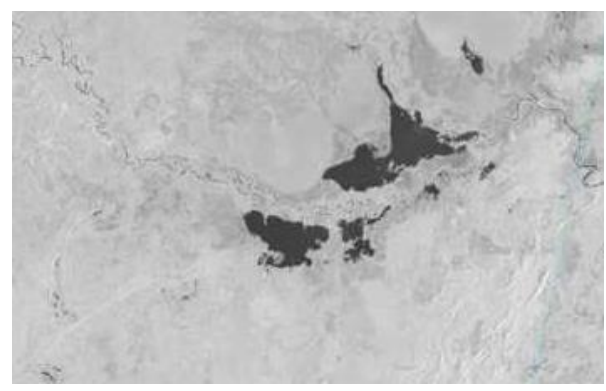

Gambar 5. Citra Sentinel-1 tahun 2018 


\section{Hasil}

Batas tetap Danau Kaskade Mahakam diperoleh dengan menggabungkan harmonic modeling 2014-2018 pada derajat 1 dan 2. Gambar 6 memperlihatkan bahwa batas tetap danau berwarna selain pink yang dihitung berdasarkan data tahun 2014-2018. Batas tetap ini sudah memenuhi kriteria pengukuran batas tepi danau minimal satu periode pasang surut atau 18,61 tahun (IHO, 2010).

Metode harmonic modeling dapat juga digunakan untuk menentukan aplikasi batas tetap yang lain seperti batas garis pantai. Hasil batas tetap ini perlu divalidasi dengan uji batas tetap danau dan grafik daratan menggunakan harmonic modeling. Pada penelitian ini uji batas tetap dilakukan dengan perbandingan relatif pada citra lain secara harmonic modeling. Hasil batas tetap ini perlu diuji akurasi dengan menguji batas tetap danau dan memeriksa grafik daratan dan air. Secara hitungan digital pada citra, luas Danau Kaskade Mahakam diperoleh 399,017 km².

Luas dan pemeriksaan batas tepi danau ini dilakukan dengan memanfaatkan identifikasi grafik pada objek daratan dan objek air. Grafik daratan digunakan untuk mengetahui bahwa titik lokasi berada di daratan (Gambar 7). Hal tersebut ditandai dari pola grafik berdasarkan harmonic modeling derajat 1 dan 2. Grafik harmonic modeling (Gambar 7) memperlihatkan batas darat dan air.

Sumbu $x$ merupakan nilai NDVI, yaitu rasio perbandingan antara reflektivitas band inframerah dikurangi band merah dan gabungan reflektivitas band inframerah dengan band merah. Nilai rasio ini tidak memiliki satuan tertentu. Sumbu y merupakan tanggal akuisisi citra satelit.

Garis warna merah merupakan nilai ideal yang dipersiapkan untuk NDVI pada objek yang sama. Garis warna biru merupakan nilai NDVI objek pada saat akuisisi citra satelit

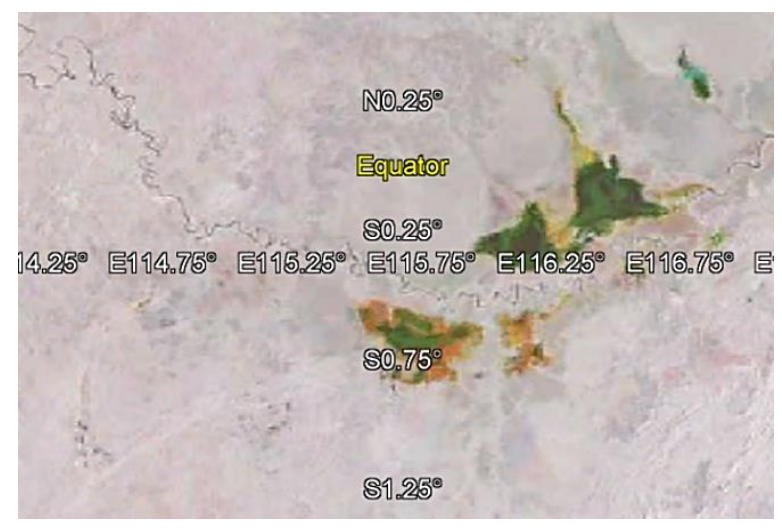

Gambar 6. Hasil batas tetap Danau Kaskade Mahakam
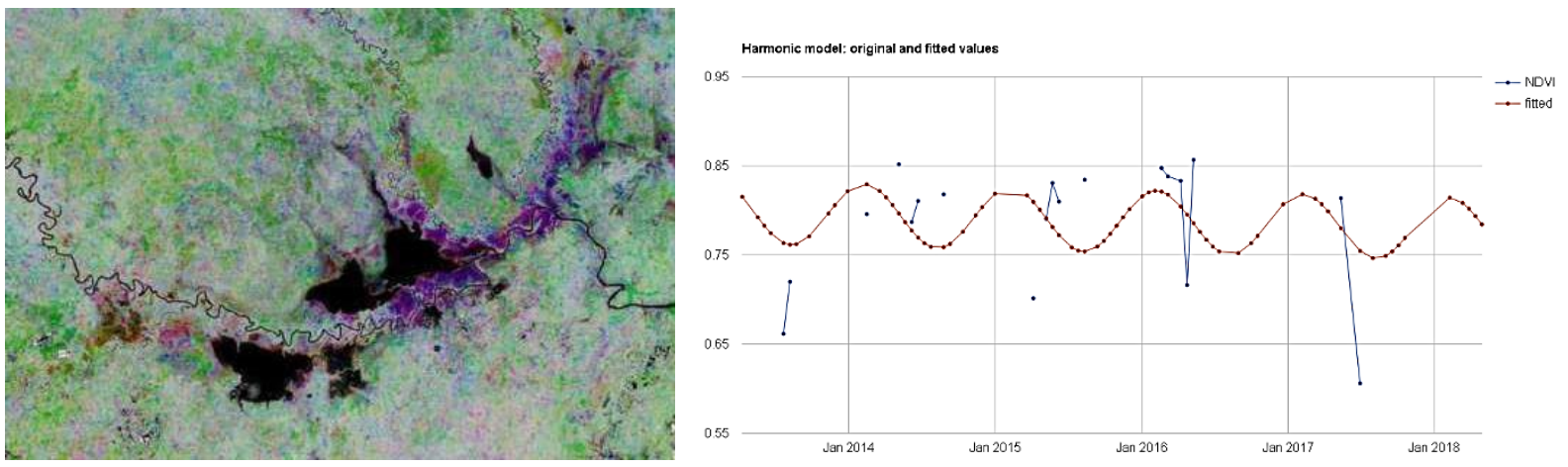

Gambar 7. Harmonic modeling derajat 2 pada daratan dengan citra Landsat tahun 2014-2018, sumbu $\mathrm{x}$ adalah nilai NDVI, sumbu y adalah waktu akuisisi citra 
Landsat. Data yang digunakan adalah citra Landsat tahun 2014-2018 dengan kondisi radiometrik surface reflectance. Selain koreksi radiometrik, koreksi geometrik juga telah dilakukan pada data ini. Harmonic modeling menggunakan derajat 1. Batas tetap danau ditunjukkan dengan warna hitam pada citra. Darat terpisah dari air secara tegas sesuai grafik warna merah (Gambar 8).

Pemeriksaan juga dilakukan dengan harmonic modeling derajat 2. Batas tetap danau diperlihatkan dengan warna hitam pada citra.
Darat terpisah dari air secara tegas sesuai grafik warna merah. Pemeriksaan yang dilakukan pada grafik air yaitu lokasi titik yang berada di air namun berdekatan dengan darat (Gambar 9).

Analisis grafik air menggunakan citra Landsat tahun 2014-2018. Koreksi geometrik dan radiometrik, serta harmonic modeling derajat 1 telah dilakukan pada data tersebut. Batas tetap danau terletak pada warna hitam (citra). Darat terpisah dari air secara tegas sesuai grafik warna merah (Gambar 10).
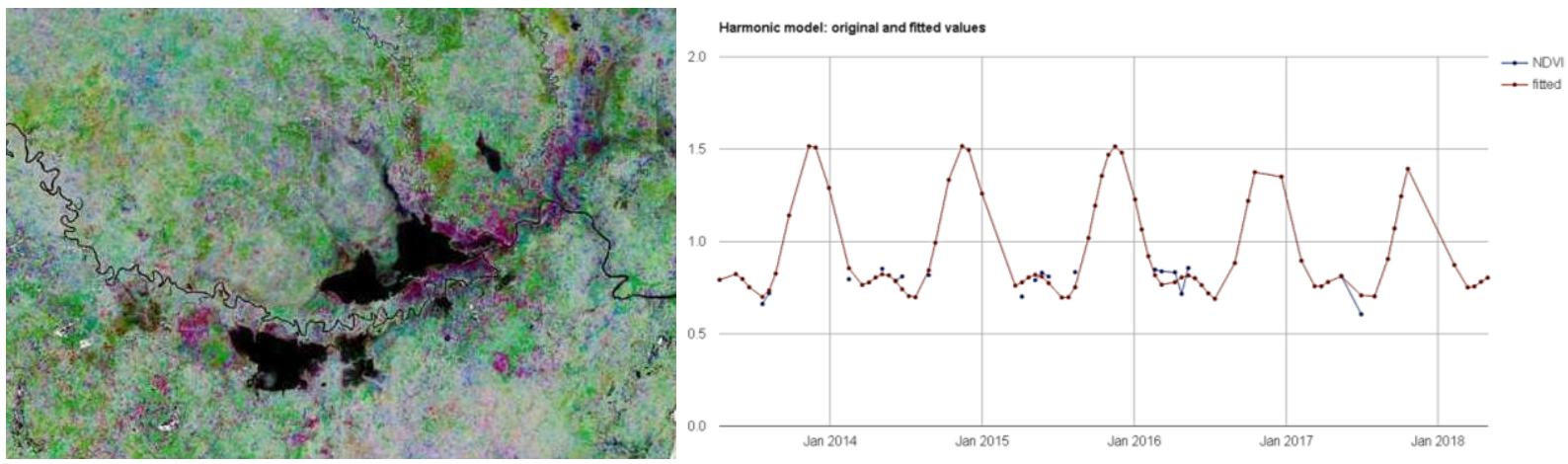

Gambar 8. Harmonic modeling derajat 2 pada daratan dengan citra Landsat tahun 2014-2018, sumbu $\mathrm{x}$ adalah nilai NDVI, sumbu y adalah waktu akuisisi citra
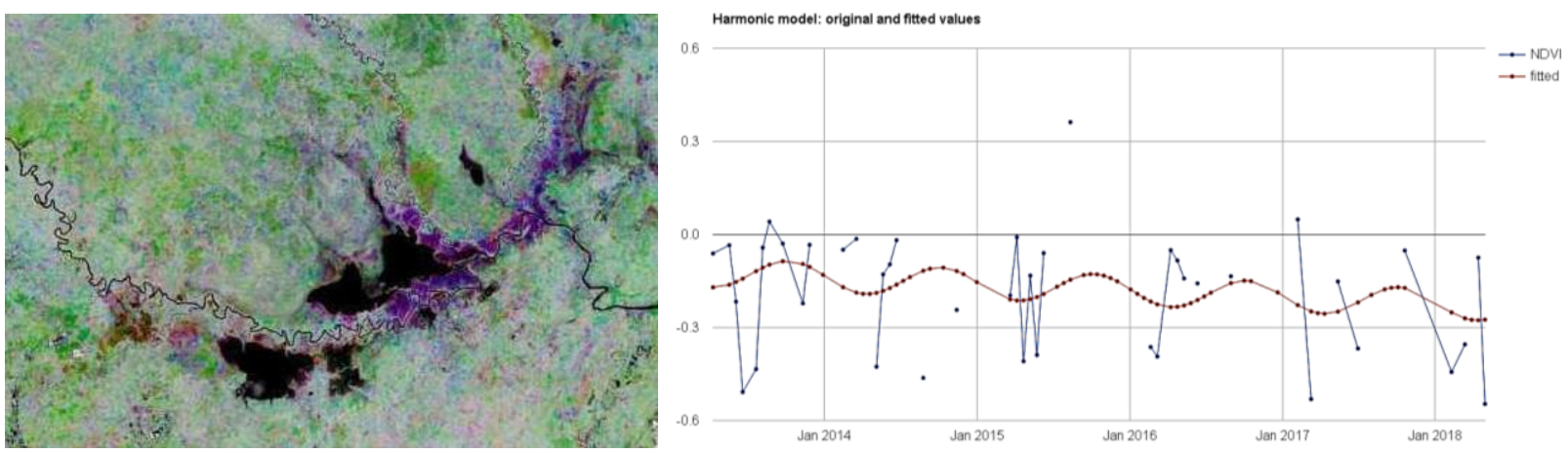

Gambar 9. Harmonic modeling derajat 1 pada air dengan citra Landsat tahun 2014-2018, sumbu x merupakan nilai NDVI, sumbu y merupakan waktu akuisisi citra 


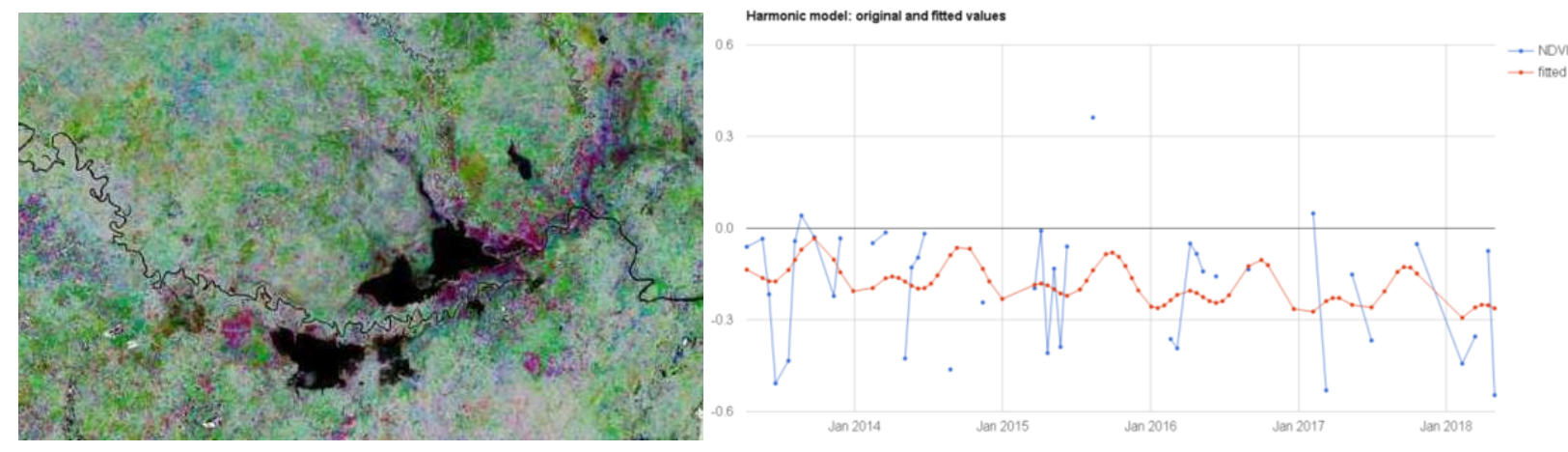

Gambar 10. Harmonic modeling derajat 2 pada air dengan citra Landsat tahun 2014-2018, sumbu x adalah nilai NDVI, sumbu y adalah waktu akuisisi citra

\section{Pembahasan}

\section{Validasi dengan Uji Batas Tetap Danau dan Grafik Harmonic Modeling Daratan dan Air \\ Hasil penghitungan menggunakan}

Persamaan 1 dan citra Sentinel-1 multitemporal, sedangkan hasil pemeriksaan menggunakan citra Landsat multitemporal. Uji batas tetap dilakukan secara 2D, 3D, dan 4D. Pada penelitian ini, pengujian dilakukan secara 2D. Pengujian dapat dilakukan dengan dua cara, yaitu pengujian terhadap batas tetap danau dari data lapangan dan pengujian dengan membandingkannya secara relatif dengan citra lain yang telah dikoreksi geometrik dan radiometrik. Batas tetap danau diperoleh dari citra Sentinel-1 multitemporal, yang kemudian diuji dengan citra Landsat multitemporal dengan harmonic modeling.

Pada penelitian ini, batas tetap danau diuji dengan cara membandingkannya dengan citra Landsat yang sudah dikoreksi geometrik dan radiometrik. Hal ini akan memudahkan dan mengurangi kesalahan dalam pengujiannya. Uji ini bersifat relatif karena citra Sentinel dan Landsat saling berhubungan satu dengan yang lain, dan keduanya dapat diakses melalui big data engine. Landsat 8 dipilih karena Sentinel-1 dan Landsat 8 memiliki persamaan, yaitu pertama kali akuisisi optimal pada sekitar tahun 2013-2014. Koreksi geometrik dan radiometrik terlebih dahulu dilakukan pada citra Landsat. Koreksi radiometrik meliputi koreksi radiometrik standar, koreksi normalisasi, koreksi topografi, dan koreksi atmosferik. Radiometrik citra Landsat berada dalam kondisi Surface Reflectance (SR).
Setelah koreksi geometrik dan radiometrik dilakukan, maka pembuatan NDVI multitemporal dan multidata kemudian dilakukan. Hal ini bertujuan untuk mengetahui perubahan vegetasi dan nonvegetasi di wilayah kajian. Kondisi tersebut memudahkan proses harmonic modeling, sehingga wilayah yang mengalami perubahan dapat diketahui. Harmonic modeling pada citra Landsat adalah derajat 1 dan 2. Pemeriksaan dilakukan secara sederhana, yaitu memeriksa daratan dan air di dekat batas tepi danau. Batas tetap terletak pada nilai NDVI (harmonic modeling) mendekati 0. Pada citra Landsat, batas tetap danau lebih cocok menggunakan harmonic modeling derajat 1 dan 2. Hal tersebut dapat dibuktikan dengan grafik daratan dan air yang digunakan dalam harmonic modeling penentuan batas danau (Gambar 7, 8, 9, dan 10). Hasil batas tetap danau pada penelitian ini merupakan batas indikatif, sehingga memerlukan penelitian lanjutan.

Citra Sentinel-1 menghasilkan luas permukaan danau $\sim 399,017 \mathrm{~km}^{2}$. Dengan citra Landsat, luas permukaan danau yang diperoleh sebesar $\sim 399,495 \mathrm{~km}^{2}$. Selisih luas permukaan danau sebesar $\sim 0,478 \mathrm{~km}^{2}$. Perbedaan ini disebabkan ada pencampuran sedimen dan kekeruhan secara tipis di pinggiran danau. Secara geostatistik, nilai yang dianggap benar masih sebesar $99,88 \%$ pada tingkat kepercayaan $1,96 \sigma$. Nilai ini bersifat relatif antara batas danau dari citra Sentinel-1 dan batas danau dari citra Landsat. Nilai ini tidak bersifat absolut karena tidak dibandingkan dengan pengukuran luas permukaan danau di lapangan. 


\section{Kesimpulan}

Penentuan dan validasi batas tetap Danau Kaskade Mahakam dapat dilakukan dengan harmonic modeling melalui pendekatan hitung perataan kuadrat terkecil. Data yang digunakan untuk menentukan batas tetap ini adalah citra Sentinel-1 dan citra Landsat tahun 2014-2018. Batas tetap diperoleh dengan melakukan penghitungan dengan metode harmonic modeling derajat 1 dan 2 pada citra Sentinel-1 dan Landsat multitemporal. Luas permukaan danau yang diperoleh dari citra Sentinel-1 sebesar $\sim 399,017 \quad \mathrm{~km}^{2}$ sedangkan luas permukaan danau berdasarkan citra Landsat diperoleh sebesar $\sim 399,495 \mathrm{~km}^{2}$. Perbedaan tersebut disebabkan ada pencampuran sedimen dan kekeruhan tipis di pinggir danau. Kondisi ini menyebabkan perbedaan nilai reflektansi pada saat perekaman kedua jenis citra tersebut. Secara prinsip, hasil yang diperoleh cukup baik dalam menentukan batas tepi danau dengan metode ini.

\section{Ucapan Terima Kasih}

Terima kasih diucapkan kepada Kementerian Riset dan Teknologi dan Pendidikan Tinggi, Universitas Gadjah Mada, Pusfatja LAPAN, Pusat Penelitian Limnologi LIPI, Balai Irigasi Kementerian PUPERA, Kementerian Kelautan dan Perikanan, Kementerian Lingkungan Hidup dan Kehutanan, Alaska University, Google Earth Engine (GEE), Blue Marble Engine (BME), dan Earth Observing System (EOS) yang telah mendukung penelitian ini. Semua penulis adalah kontributor utama dalam tulisan ini.

\section{Referensi}

Adjei ZY. 2015. Using Remote Sensing to Explore the Time History of Emergent Vegetation at Malheur Lake, Oregon. A Master thesis at the Faculty of Brigham Young University, Department of Civil and Environmental Engineering

Artis MJ, Clavel JG, Hoffmann M, Nachane DM. 2007. Harmonic Regression Models: A Comparative Review with Applications. Ssrn. DOI: 10.2139/ssrn.1017519

Asdak C. 2014. Hidrologi dan Pengelolaan
Daerah Aliran Sungai. Gadjah Mada University Press, Yogyakarta

Baig MHA, Zhang L, Shuai T, Tong Q. 2014. Derivation of a tasselled cap transformation based on Landsat 8 at-satellite reflectance. Remote Sensing Letters 5: 423-431. DOI: 10.1080/2150704X.2014.915434

Bayr C, Gallaun H, Kleb U, Kornberger B, Steinegger M, Winter M. 2016. Satellitebased forest monitoring: spatial and temporal forecast of growing index and short-wave infrared band. Geospatial Health 11. DOI: $10.4081 / \mathrm{gh} .2016 .310$

Blanco PD, del Valle HF, Bouza PJ, Metternicht GI, Hardtke LA. 2014. Ecological site classification of semiarid rangelands: Synergistic use of Landsat and Hyperion imagery. International Journal of Applied Earth Observation and Geoinformation 29: 11-21. DOI: 10.1016/j.jag.2013.12.011

Blume T, van Meerveld I, Weiler M. 2017. The role of experimental work in hydrological sciences-insights from a community survey. Hydrological Sciences Journal 62: 334-337. DOI: 10.1080/02626667.2016.1230675

Bradley BA, Jacob RW, Hermance JF, Mustard JF. 2007. A curve fitting procedure to derive inter-annual phenologies from time series of noisy satellite NDVI data. Remote Sensing of Environment 106: 137-145. DOI: 10.1016/j.rse.2006.08.002

Brezonik PL, Kloiber SM, Olmanson LG. 2002. Satellite and GIS tools to assess lake quality. University of Minnesota, Water Resources Center, Technical Report 145

Buma WG, Lee S Il, Seo JY. 2018. Recent surface water extent of lake Chad from multispectral sensors and GRACE. Sensors (Switzerland) 18. DOI: 10.3390/s18072082

Benjamin, G., Yaw, M.A., Eric, T.T., Eric, K.F., 2016. Mapping the spatial changes in Lake Volta using multitemporal remote sensing approach. Lakes and Reservoirs. Lakes Reserv. Res. Manag., 21: 206-215

Canty MJ. 2010. Image Analysis, Classification and Change Detection in Remote Sensing, With Algorithms for ENVI/IDL, Second edition. Taylor and Francis, CRC Press

Coppin P, Jonckheere I, Nackaerts K, Muys B, Lambin E. 2004. Digital change detection methods in ecosystem monitoring: A review. International Journal of Remote Sensing 25: 1565-1596. DOI: $10.1080 /$ 


\section{5}

Doxaran D, Froidefond J-M, Castaing P. 2002. A reflectance band ratio used to estimate suspended matter concentrations in sediment-dominated coastal waters A re ectance band ratio used to estimate suspended matter concentrations in sediment-dominated coastal w. Int. J. Remote Sensing 23: 5079-5085. DOI: $10.1080 / 0143116021000009912$ org/10.1080 / 0143116021000009912

Duan Z, Gao H, Ke C. 2018. Estimation of lake outflow from the poorly gauged Lake Tana (Ethiopia) using satellite remote sensing data. Remote Sensing 10: 1-21. DOI: 10.3390/rs10071060

Duan Z, Liu J, Tuo Y, Chiogna G, Disse M. 2016. Evaluation of eight high spatial resolution gridded precipitation products in Adige Basin (Italy) at multiple temporal and spatial scales. Science of the Total Environment 573: 1536-1553. DOI: 10.1016/j.scitotenv.2016.08.213

Definiens, 2016. Reference Book: Definiens Professional version 5.0.6.2. Defineiens AG. München, Germany

ESA, 2018. Sentinel Satellite. ESA. Belanda

Freeden W, Nashed Z, Sonar T, 2010. Handbook of Geomathemathics. Springer. ISBN: 9783642015465

Gillani C, Wolf. 2006. Adjustment Computation: Spatial Data Analysis. John Wiley and Sons, Inc., Hoboken, New Jersey. Amerika Serikat

GEE, 2018. Google Earth Engine. Google. Amerika Serikat

Geerken RA. 2009. An algorithm to classify and monitor seasonal variations in vegetation phenologies and their interannual change. ISPRS J. Photogramm. Remote Sens., 64 (4) (2009), pp. 422-431, 10.1016/j.isprsjprs.2009.03.001

Gao H, Hrachowitz M, Fenicia F, Gharari S, Savenije H. 2014. Testing the realism of a topography-driven model (FLEX-topo) in the nested catchments of the Upper Heihe, China. Hydrol. Earth Syst. Sci., 18: 18951915

Hidayat H, Hoekman DH, Vissers MAM, Hoitink AJF. 2012. Flood occurrence mapping of the middle Mahakam lowland area using satellite radar, Hydrol. Earth Syst. Sci., 16: 1805-1816, https://doi.org/10.5194/hess-16-1805-2012,
2012

Hickmat H, Abdelazim N. 2016. Change detection in the water bodies of Burullus Lake, Northern Nile Delta, Egypt, using RS/GIS. Procedia Eng., 154: 951-958

Honda KL, Samarakoon A, Ishibashi Y, Mabuchi S, Miyajima. 1996. Remote Sensing and GIS technologies for denudation estimation in Siwalik watershed of Nepal. p. B21-B26 Proc. 17th Asian Conference on Remote Sensing, Colombo, Sri lanka. 4-8 November 1996

Hermance JF. 2007. Stabilizing high-order, non-classical harmonic analysis of NDVI data for average annual models by damping model roughness. Int. J. Remote Sens., 28(12): 2801-2819, 10.1080/01431160600967128IHO, 2010. A manual on technical aspect of the united nation convention on the law of the sea. International Hydrographic Bureau, Monaco.

Julzarika A, Laksono DP, Subehi L, Dewi EK, Kayat, Sofiyuddin HA, Nugraha MFI. 2018. Comprehensive integration system of saltwater environment on Rote Island using a multidisciplinary approach. J. Degrade. Min. Land Manage 6(1): 1553-1567, DOI: 10.15243/jdmlm. 2018.061.1553

Kamran KV, Khorrami B. 2018. Change Detection and Prediction of Urmia Lake and its Surrounding Environment During the Past 60 Years Applying Geobased Remote Sensing Analysis. The International Archives of the Photogrammetry, Remote Sensing and Spatial Information Sciences, Volume XLII-3/W4, GeoInformation For Disaster Management (Gi4DM), 18-21 March 2018, Istanbul, Turkey

Karimi P, Bastiaanssen WG. 2015. Spatial evapotranspiration, rainfall and land use data in water accounting-Part 1: Review of the accuracy of the remote sensing data. Hydrol. Earth Syst. Sci., 19: 507-532

Kartika T, Trisakti B, Suwargana N. 2015. Pemanfaatan Data Penginderaan Jauh Landsat-8 untuk Mengamati Nilai TSS dan Kecerahan Perairan Danau Toba, Sumatera Utara. Prosiding Sinas Inderaja 2015. Jakarta

Kementerian Lingkungan Hidup Republik Indonesia. 2008. Pedoman Pengelolaan Ekosistem Danau. Kementerian Lingkungan Hidup, Jakarta 
Kementerian Lingkungan Hidup Republik Indonesia. 2011. Profil 15 Danau Prioritas Nasional. Kementerian Lingkungan Hidup, Jakarta

Kumay DU. 2015. Remote sensing platforms and sensor. NBKRIST Vidyanagar. India

Li R, Li J. 2004. Satellite Remote Sensing Technology for Lake Water Clarity Monitoring: An Overview. International Society for Environmental Information Sciences, Environmental Informatics Archives 2: 893-901

LIPI. 2018. Limnologi LIPI. diakses Juli 2018. http://www.limnologi.lipi.go.id/ aboutus.php?id=2.

Liu J, Hirose T, Kapfer M, Bennett J. 2007. Operational Water Quality Monitoring Over Lake Winnipeg Using Satellite Remote Sensing Data. Our Common Borders Safety, Security, and the Environment Through Remote Sensing, October 28 November 1, 2007, Ottawa, Ontario, Canada

Maillard P, Pivari MO, Luis CHP. 2012. Remote Sensing for Mapping and Monitoring Wetlands and Small Lakes in Southeast Brazil. Open Journal Intech. www.intechopen.com

Marianthi S, Eleni C, Eleni K. 2011. Monitoring Lake Ecosystems Using Integrated Remote Sensing / GIS Techniques: An Assessment in the Region of West Macedonia, Greece. DOI: 10.5772/27926. Open Journal Intech, ISBN 978-953-307-724-6

Mostafa MM, Soussa HK. 2006. Monitoring of Lake Nasser Using Remote Sensing and Gis Techniques, ISPRS Commission VII Midterm Symposium "Remote Sensing: From Pixels to Processes", Enschede, the Netherlands, 8-11 May 2006

Pekel JF, Cottam A, Gorelick N, Belward AS. 2016. High-resolution mapping of global surface water and its long-term changes. Nature 540: 418-422. DOI: 10.1038/nature20584

Powell R, Brooks C, French N, Shuchman R. 2008. Remote Sensing of Lake Clarity. Michigan Tech Research Institute (MTRI), May 2008

Pratisto A, Danoedoro P. 2008. The impact of land use changes against flood discharge and flood hazard (case study in Gesing Watershed, Purworejo, based on Landsat TM and ASTER VNIR image. Proceedings of the Annual Scientific Meeting of the Indonesian Remote Sensing Soceity (PITMAPIN), Bandung

Priasty EW. 2014. Analisis Dampak Perubahan Penggunaan Lahan Terhadap Daerah Aliran Sungai di Kabupaten Bengkulu Utara, Jurnal Bengkulu Mandiri. https://usantoso.wordpress.com/2014/01/04/ analisis-dampak-perubahan-penggunaanlahan-terhadap-daerah-aliran-sungai-dikabupaten-bengkulu-utara/

Pye K, Croft DJ. 2004. Forensic Geoscience: Principles, Techniques and Applications. Geological Society, London, Special Publications, 232, 1-5. 9 The Geological Society of London

Senay GB, Velpuri NM, Bohms S, Demissie Y, Gebremichael M. 2014. Understanding the hydrologic sources and sinks in the Nile Basin using multisource climate and remote sensing data sets. Water Resour. Res. 50: 8625-8650

Soetaat. 1996, Hitung kuadrat terkecil lanjut, Geodesy and Geomatics Engineering, University of Gadjah Mada, Yogyakarta

Suroso, Susanto HA. 2006. Pengaruh Perubahan Tata Guna Lahan Terhadap Debit Banjir Daerah Aliran Sungai Banjaran, Jurnal Teknik Sipil Vol. 3, No. 2, Juli 2006

Tang G, Long D, Hong Y. 2016. Systematic anomalies over inland water bodies of High Mountain Asia in TRMM precipitation estimates: No longer a problem for the GPM era? IEEEGeosci. Remote Sens. Lett. 13: 1762-1766

Tauro F, Selker J, van de Giesen N, Abrate T, Uijlenhoet R, Porfiri M, Manfreda S, Caylor K, Moramarco T, Benveniste J. 2018. Measurements and observations in the XXI century (MOXXI): Innovation and multidisciplinarity to sense the hydrological cycle. Hydrol. Sci. J. 63: 169-196

Trisakti B. 2013. Kajian Penentuan Luas Danau dan Sebaran Vegetasi Air dengan Metoda Penginderaan Jauh, LIMNOTEK Perairan Darat Tropis di Indonesia 20(1): 10-20

Trisakti B, Suwargana N, Cahyono JK. 2014. Pemanfaatan Data Penginderan Jauh Untuk Memantau Parameter Status Ekosistem Perairan Danau (Studi Kasus: Danau Rawa Pening). Seminar Nasional Penginderaan Jauh Nasional 2014

Trisakti B, Julzarika A, Dewi EK. 2016. Pemanfaatan Standar Pemanfaatan Data 
Penginderaan Jauh Untuk Pemantauan Perubahan Lahan. Laporan kegiatan pusat pemanfaatan penginderaan jauh, LAPAN, Jakarta

United Nation (UN). 1982. UNCLOS 1982. United Nation

United States of Geological Survey (USGS), 2018. Landsat Mission. USGS. diakses Juli 2018. https://landsat.usgs.gov/. Amerika Serikat

Wasige JE. 2013. Monitoring Basin-Scale Land Cover Changes in Kagera Basin of Lake Victoria using Ancillary Data and Remote Sensing. International Journal of Applied Earth Observation and Geoinformation 21: 32-42

Wilson BT, Knight JF, McRoberts RE. 2018. Harmonic regression of Landsat time series for modeling attributes from national forest inventory data. https://doi.org/10.1016/j.isprsjprs.2018.01.0 060924-2716/Published by Elsevier B.V. International Society for Photogrammetry and Remote Sensing, Inc. (ISPRS)

Wolf PR. 1981, Adjustment Computations: (practical least square for surveyors), 2nd edition, Institute Technology of Bandung, Bandung

Zheng S, Cao C, Dang Y, Xiang H, Zhao J, Zhang Y, Wang X, Guo H. 2014. Retrieval of forest growing stock volume by two different methods using Landsat TM images. Int. J. Remote Sens. 35(1): 29-43. https://doi.org/10.1080/ 01431161.2013 .860567

Zhu X, Liu D. 2015. Improving forest aboveground biomass estimation using seasonal Landsat NDVI time-series. ISPRS J. Photogramm. Remote Sens. 102 (Suppl. C): 222-231. https://doi.org/10.1016/ j.isprsjprs.2014.08.014

Zimmerman DL, Cressie N. 1992. Mean squared prediction error in the spatial linear model with estimated covariance parameters. Annuals of the Institute of Statistical Mathematics 44: 27-43 